\title{
Meso-scale atmospheric events promote phytoplankton blooms in the coastal Bay of Bengal
}

\author{
K Maneesha $^{1}$, V V S S Sarma ${ }^{1, *}$, N P C Reddy ${ }^{1}$, Y Sadhuram ${ }^{1}$, \\ T V Ramana Murty ${ }^{1}$, V V Sarma ${ }^{1}$ and M Dileep Kumar ${ }^{2}$ \\ ${ }^{1}$ National Institute of Oceanography (Council of Scientific and Industrial Research), \\ 176 Lawsons Bay Colony, Visakhapatnam 530 017, India. \\ ${ }^{2}$ National Institute of Oceanography (Council of Scientific and Industrial Research), \\ Dona Paula, Goa 403 004, India. \\ *e-mail:sarmav@nio.org
}

The Bay of Bengal is considered to be a low productive region compared to the Arabian Sea based on conventional seasonal observations. Such seasonal observations are not representative of a calendar year since the conventional approach might miss episodic high productive events associated with extreme atmospheric processes. We examined here the influence of extreme atmospheric events, such as heavy rainfall and cyclone Sidr, on phytoplankton biomass in the western Bay of Bengal using both in situ time-series observations and satellite derived Chlorophyll $a$ (Chl $a$ ) and sea surface temperature (SST). Supply of nutrients through the runoff driven by episodic heavy rainfall (234 mm) on 4-5 October 2007 caused an increase in Chl $a$ concentration by four times than the previous in the coastal Bay was observed within two weeks. Similar increase in Chl $a$, by 3 to 10 times, was observed on the right side of the cyclone Sidr track in the central Bay of Bengal after the cyclone Sidr. These two episodic events caused phytoplankton blooms in the western Bay of Bengal which enhanced $\sim 40 \%$ of fishery production during October-December 2007 compared to that in the same period in 2006.

\section{Introduction}

The northeastern Indian Ocean (Bay of Bengal) is bounded by landmass except in the south and covers an area of $2.2 \times 10^{6} \mathrm{~km}^{2}$ (Lafond 1966). The surface circulation of the Bay of Bengal undergoes reversals forced by seasonal changes in monsoon winds (Shetye et al 1996). The winds blow from northeast during November-February, southerly in April, and southwest from June to October (Varkey et al 1996). The immense fresh water discharge from major rivers, such as Ganges, Brahmaputra, Godavari, led to the formation of strong surface stratification (UNESCO 1979). The Bay of Bengal is known to be a region of lower biological productivity (Qasim 1977; Radhakrishna et al 1978) than the Arabian Sea due to light inhibition by water turbidity, low vertical nutrient supply and cloud cover (Gomes et al 2000; Madhupratap et al 2003 and references therein). Prasanna Kumar et al (2002) noted that less supply of nutrients due to strong stratification resulted in low primary production in the Bay of Bengal during the summer monsoon. The main mechanism of nutrients supply to surface ocean is the vertical supply from subsurface layers. Even under strong wind forcing,

Keywords. Chlorophyll; cyclone; primary production; short-term variations; rainfall; atmospheric disturbances; extreme events. 
surface stratification in the Bay of Bengal is only weakly disrupted (Patra et al 2007), and hence the supply of nutrients through vertical mixing will be limited.

The influence of physical processes (upwelling and Ekman pumping), fresh water discharge and cyclones on the distribution of Chlorophyll $a(\mathrm{Chl} a)$ in Bay of Bengal on annual scale had been studied by Vinaychandran (2009). High Chl $a$ concentrations were observed off river mouths coinciding with the peak discharge season. Vinaychandran (2009) further observed that $\mathrm{Chl} a$ rich waters off Ganga and Brahmaputra river flows were carried southward during spring and spread along the Indian coast during winter and summer. Cyclones, eddies and circulation pattern have significant influence on distribution of Chl $a$ in the Bay of Bengal. Nayak et al (2001) observed that nutrients supplied by super cyclone (25-29 October 1999) enhanced Chl $a$ concentrations (5-10 times) along the central west coast of the Bay of Bengal. Madhu et al (2002) also noted enhanced nutrient concentrations (nitrate by $1 \mu \mathrm{M}$ ) and the consequent increase in primary production (by 21 to $955 \mathrm{mgC} \mathrm{m}^{-2} \mathrm{~d}^{-1}$ ) in the south western Bay of Bengal by the super cyclone of 1999 . Satellite Chl $a$ imageries revealed the occurrence of phytoplankton bloom in the southwestern Bay during NE monsoon due to upwelling caused by cyclones (Vinayachandran and Mathew 2003). Rao et al (2006) also reported the occurrence of phytoplankton blooms in the southern Bay of Bengal caused by a cyclone in November-December 2000 . The above studies brought out the importance of cyclones on phytoplankton blooms in the Bay of Bengal. The Bay of Bengal experienced two extreme atmospheric events: (i) an extreme rainfall and (ii) the cyclone Sidr during October-November 2007 and that are discussed in detail below:

(1) Extreme rainfall event: Northeast-southwest oriented trough occurred off Andhra to south
Orissa coast on 30th September 2007 that intensified into a low pressure system $(1002 \mathrm{mb})$ and centred over Visakhapatnam region (figure 1), which caused heavy rainfall during $4-5$ th October 2007. The rainfall recorded at the India Meteorological Department (IMD) observatory of Visakhapatnam was $234 \mathrm{~mm}$, while it was $264 \mathrm{~mm}$ and $209 \mathrm{~mm}$ at Naval Meteorological Office. Doppler Weather Radar (DWR) observations also captured this extreme rainfall over a large area (Venkateswarlu and Sudhavalli 2010). IMD observatory was very close to the coast and the other locations were about $15 \mathrm{~km}$ away from coast. Heavy and flash floods occurred in the city and most of this water drained into the sea close to our study area (figure 1). The normal monthly rainfall at Visakhapatnam for October was $238 \mathrm{~mm}$ (average for the period 1968-2000; www.imd.gov.in). However, a rainfall of 209-264 mm occurred just in a day on 4-5 October 2007.

(2) Cyclone Sidr: Convective clouds occurred over the southeast Andaman Sea on 9th November favoured a low pressure system on 11th November 2007. It moved in a northwesterly direction initially and intensified as a cyclone $(S i d r)$ by 12th November 2007. It further intensified to a very severe cyclone and moved in a northerly direction. The lowest central pressure of $944 \mathrm{mb}$ with maximal winds of $58 \mathrm{~m} \mathrm{~s}^{-1}$ was observed. The storm crossed west Bangladesh at 1700 UTC on 15th November 2007 and created a storm surge of about $4-5 \mathrm{~m}$ height. This was the most powerful cyclone to hit Bangladesh since 1991. More than 3000 people were killed and the total loss due to Sidr was 1.6 billion dollars (IMD 2008). The track of the storm is shown in figure 1.

The objective of the present study is to examine the influence of the above extreme events on

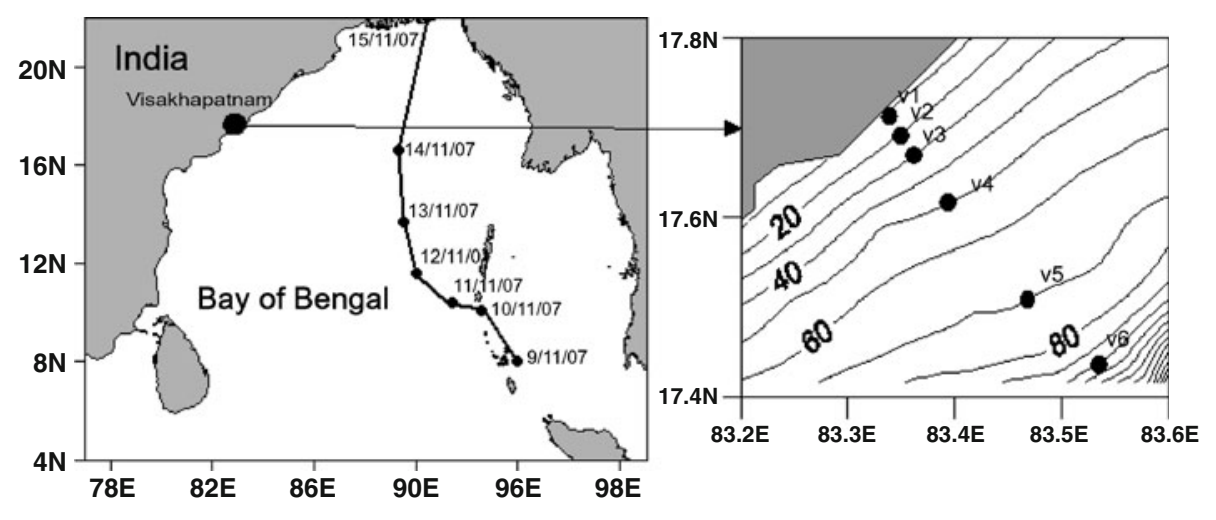

Figure 1. Transect (V1-V6) off Visakhapatnam is shown along with bathymetry. The track of the cyclone Sidr during 1115 November 2007 over the Bay of Bengal is also shown. Data on storm track positions and wind speed ( $\mathrm{m} \mathrm{s}^{-1}$ ) at 3 hourly intervals were obtained from IMD Report (2008). 
phytoplankton blooms with a combination of both in situ observations and satellite data for the first time.

\section{Data}

Six stations with water depths of $10,20,30,50$, 75 , and $100 \mathrm{~m}$ (spread up to $30 \mathrm{~km}$ from the coast) along the transect off Visakhapatnam (figure 1) were sampled every month since October 2006. Vertical profiles of pressure, temperature and salinity were measured using portable conductivity, temperature and depth (CTD) profiler (SBE 19 plus, SeaBird Electronics Inc., USA). Water samples were collected using 5/10-litre Niskin bottles using a hydrographic wire. Concentrations of nutrients were measured following standard spectrophotometric procedures (Grasshoff et al 1983). The precision of nitrate+nitrite, phosphate and silicate were $\pm 0.02, \pm 0.01$ and $\pm 0.02 \mu \mathrm{mol} \mathrm{l} \mathrm{l}^{-1}$, respectively. A 2-l water sample was filtered through $\mathrm{GF} / \mathrm{F}(0.7 \mu \mathrm{m}$ pore size; Whatman). Chl $a$ retained on the filter was first extracted with N,N dimethyl formamide (DMF), at $4^{\circ} \mathrm{C}$ in dark for $12 \mathrm{~h}$ and then spectrofluorometrically (Cary Eclipse spectrofluorophotometer, Varian Instruments) analysed following Suzuki and Ishimaru (1990). The analytical precision for Chl a analysis was $\pm 4 \%$. Data collected along the transect in 2006 (18 October, 28 November) and in 2007 (18 October, 27 November) were used in this study to examine the influence of extreme atmospheric events on phytoplankton blooms.

Weekly composite maps (Level 3) of Chl $a$ derived from Moderate Resolution Imaging Spectroradiometer (MODIS) and SeaWiFS (Sea-viewing Wide Field-of-view Sensor) at $9 \mathrm{~km}$ spatial resolution, and sea surface temperature (SST) from Aqua MODIS (downloaded from Goddard Space Flight Centre (GSFC), http://oceancolor.gsfc.nasa.gov) were used. The SST was also obtained from MISST (Multi Sensor Improved Sea Surface Temperature; www.misst.org/data_servers/data_servers.html) at $25 \mathrm{~km}$ spatial resolution. The advantage of MISST is the availability in the presence of cloud, which is not possible with MODIS. Near-real time surface currents data were retrieved from TOPEXPOSIDEON altimeter (www.aoml.noaa.gov). Utilising both in situ and satellite datasets, the

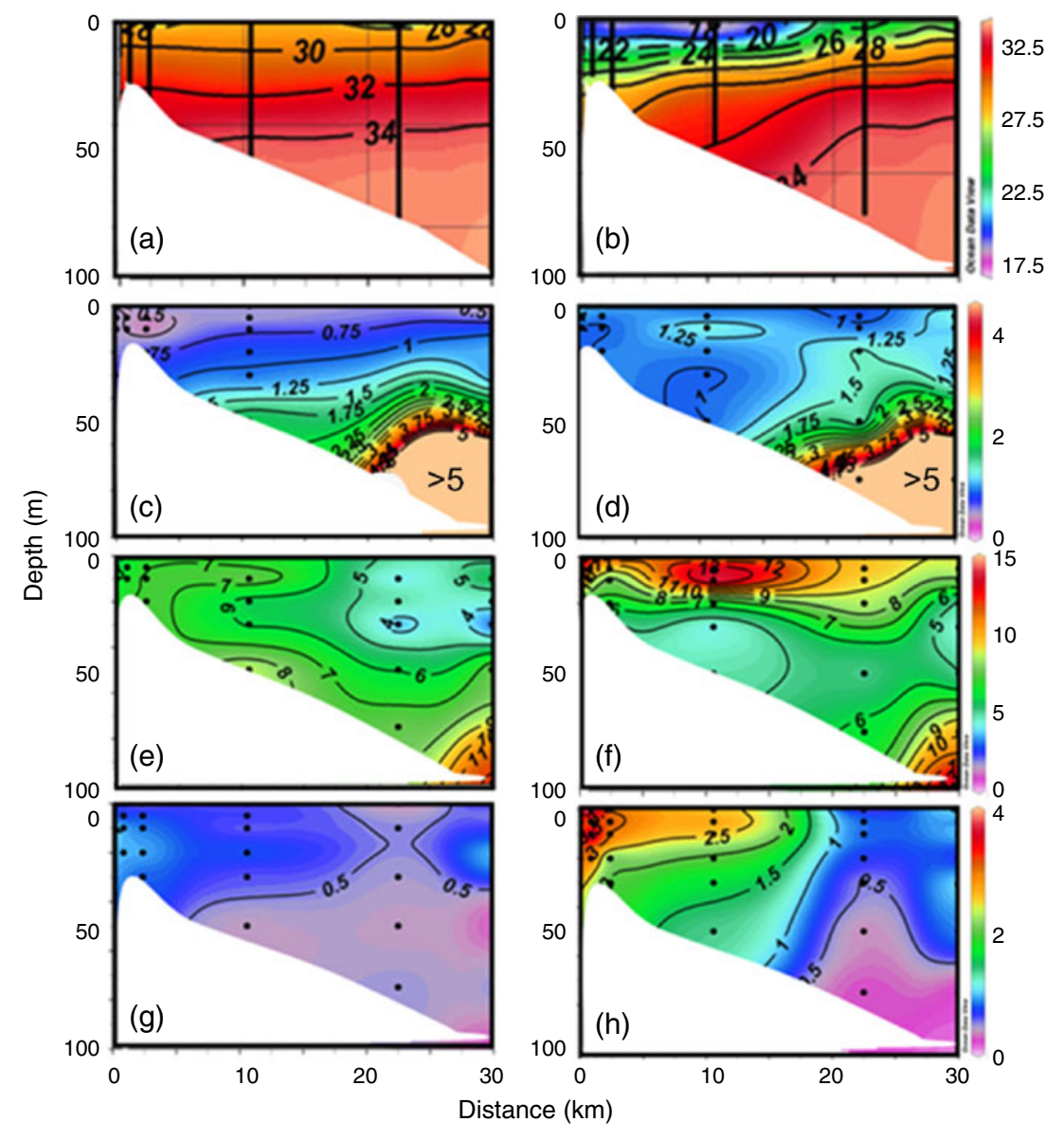

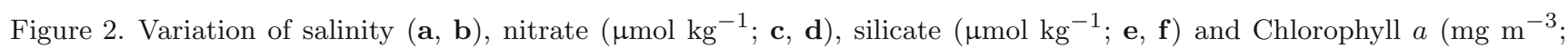
$\mathbf{g}, \mathbf{h}$ ) during October 2006 (normal) and October 2007 (after extreme rainfall event), respectively. 
impacts of (a) extreme rainfall due to low pressure and (b) the cyclone Sidr in the generation of phytoplankton blooms in the western Bay of Bengal have been analysed and discussed.

\section{Results and discussion}

\subsection{Occurrence of phytoplankton blooms driven by extreme rainfall due to a brief low pressure event}

In October 2006, surface salinity was $\sim 28$ in the coastal waters off Visakhapatnam with a vertical gradient of $\sim 6$ from surface to $50 \mathrm{~m}$ (figure 2a). Due to heavy rainfall on 4-5th October 2007, salinity decreased to $\sim 18$ in the upper $5 \mathrm{~m}$ of water column with a vertical gradient of $\sim 14$ in upper $50 \mathrm{~m}$ on 18 th October 2007 (figure 2b). Though relatively low salinity occurred in the entire transect during October 2007, it increased offshore. The low coastal salinity water of October 2007 was associated with high nutrients $\left(>1.0 \mu \mathrm{mol} \mathrm{\textrm {kg } ^ { - 1 }}\right.$ of nitrate) compared to that in October 2006 $\left(\sim 0.5 \mu \mathrm{mol} \mathrm{kg}{ }^{-1}\right.$; figure $\left.2 \mathrm{c}, \mathrm{d}\right)$. Similarly dissolved silicate concentration also reached a maximum of $\sim 15 \mu \mathrm{mol} \mathrm{kg}{ }^{-1}$ in October 2007 compared to that of $\sim 6 \mu \mathrm{mol} \mathrm{kg} \mathrm{kg}^{-1}$ in October 2006 (figure 2e, f). In response to nutrients supply by the extreme rainfall event a significant increase in $\mathrm{Chl} a(2.5-$ $3.5 \mathrm{mg} \mathrm{m}^{-3}$ ) was found during October 2007 compared to that in October $2006\left(\sim 0.5-0.8 \mathrm{mg} \mathrm{m}^{-3}\right)$ in the near shore region (stations V1-V4, about $12 \mathrm{~km}$ from coast; figure 2h). Sarma et al (2006) reported low concentration of $\mathrm{Chl} a\left(0.17 \mathrm{mg} \mathrm{m}^{-3}\right)$ off Visakhapatnam also during October 2000 when no extreme event occurred. Higher silicate concentration during October 2007 indicates that nutrients were mainly brought by land drainage. Nutrients also increased at the offshore stations V5 and V6, located during 2007 compared to that in 2006 (figure 2).

Cloud free, in the region of interest, weekly mean images displayed significant increase in Chl $a$ $\left(>1 \mathrm{mg} \mathrm{m}^{-3}\right)$ during 30 September to 7 October 2007 compared to that of 14-21 September 2007 $\left(<0.2 \mathrm{mg} \mathrm{m}^{-3}\right)$ in the region between $16^{\circ} \mathrm{N}$ and $20^{\circ} \mathrm{N}$ along the east coast of India (figure $3 \mathrm{a}-\mathrm{e}$ ). In general, northeasterly winds prevail during October along the east coast of India. However, southwesterlies occurred during October 2007, due to presence of low pressure area at Andhra and Orissa coasts, resulting in heavy precipitation. This led to the prevalence of low saline and nutrient rich waters beyond $30 \mathrm{~km}$ from the coast (figure $2 \mathrm{~b}$ ) and supported rapid increase in $\mathrm{Chl} a$ from 30 September to 7 October 2007 (figure $2 \mathrm{c}-\mathrm{f}$ ). Chl $a$ decreased to normal levels $\left(\sim 0.1 \mathrm{mg} \mathrm{m}^{-3}\right)$ in the following two weeks (23-31 October 2007) due to rapid utilization of nutrients or dilution by surface currents (figure 3). Though low pressure cell prevailed over $100 \mathrm{~km}$ area, centering above Visakhapatnam, the observed high Chl a patch during 30 September7 October 2007 extended to about $300 \mathrm{~km}$ along the west coast of Bay of Bengal (figure $3 \mathrm{~b}$ ). This could have possibly resulted from the meandering of EICC, which transports coastal waters to few hundred kilometres offshore (Vinaychandran 2009). Altimeter data suggested that equatorward flow of EICC was strong $\left(\sim 1 \mathrm{~m} \mathrm{~s}^{-1}\right)$ during the study period and might have facilitated the southward spread of phytoplankton bloom (figure 4a, b). The primary production increased by 3 times in October $2007\left(18-69 \mathrm{mgC} \mathrm{m}^{-3} \mathrm{~d}^{-1}\right)$ compared to September $2007\left(5-18 \mathrm{mgC} \mathrm{m} \mathrm{m}^{-3} \mathrm{~d}^{-1}\right)$. This study, therefore, shows that the episodic heavy rainfall event drained significant amounts of nutrients to the coastal Bay of Bengal and promoted a phytoplankton bloom over the period of about 2 weeks.

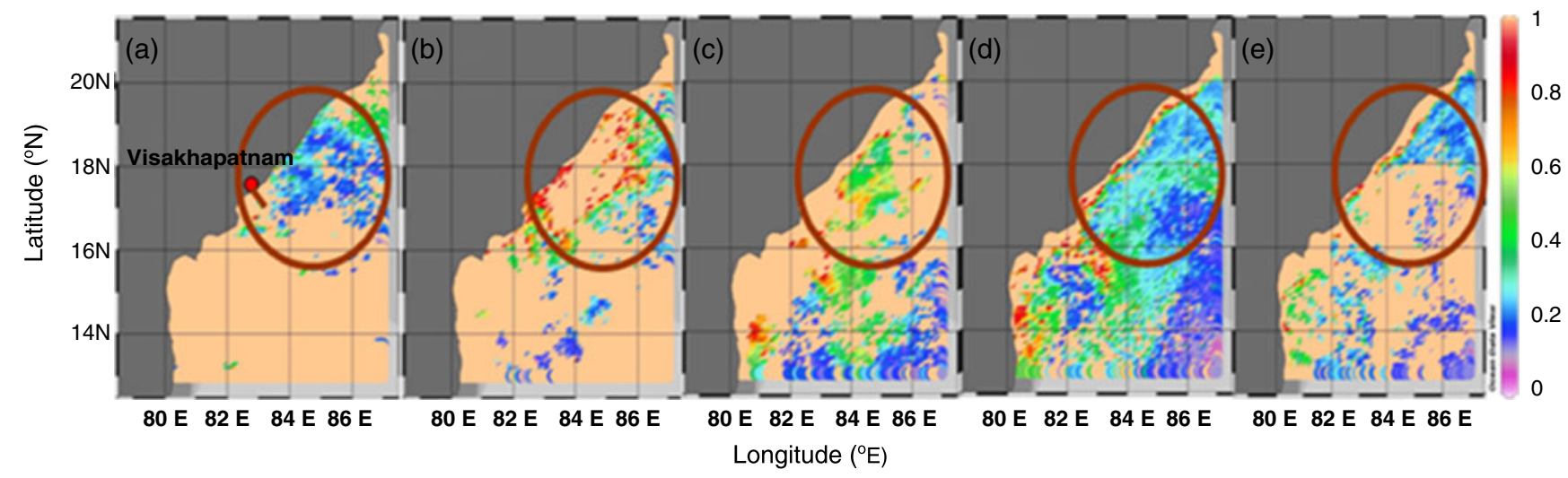

Figure 3. Changes in weekly mean Chlorophyll $a\left(\mathrm{mg} \mathrm{m}^{-3}\right)$ in the northwestern Bay of Bengal: (a) 14-21 September, (b) 30 September-7 October, (c) 8-15 October, (d) 16-23 October, and (e) 23-31 October 2007. 


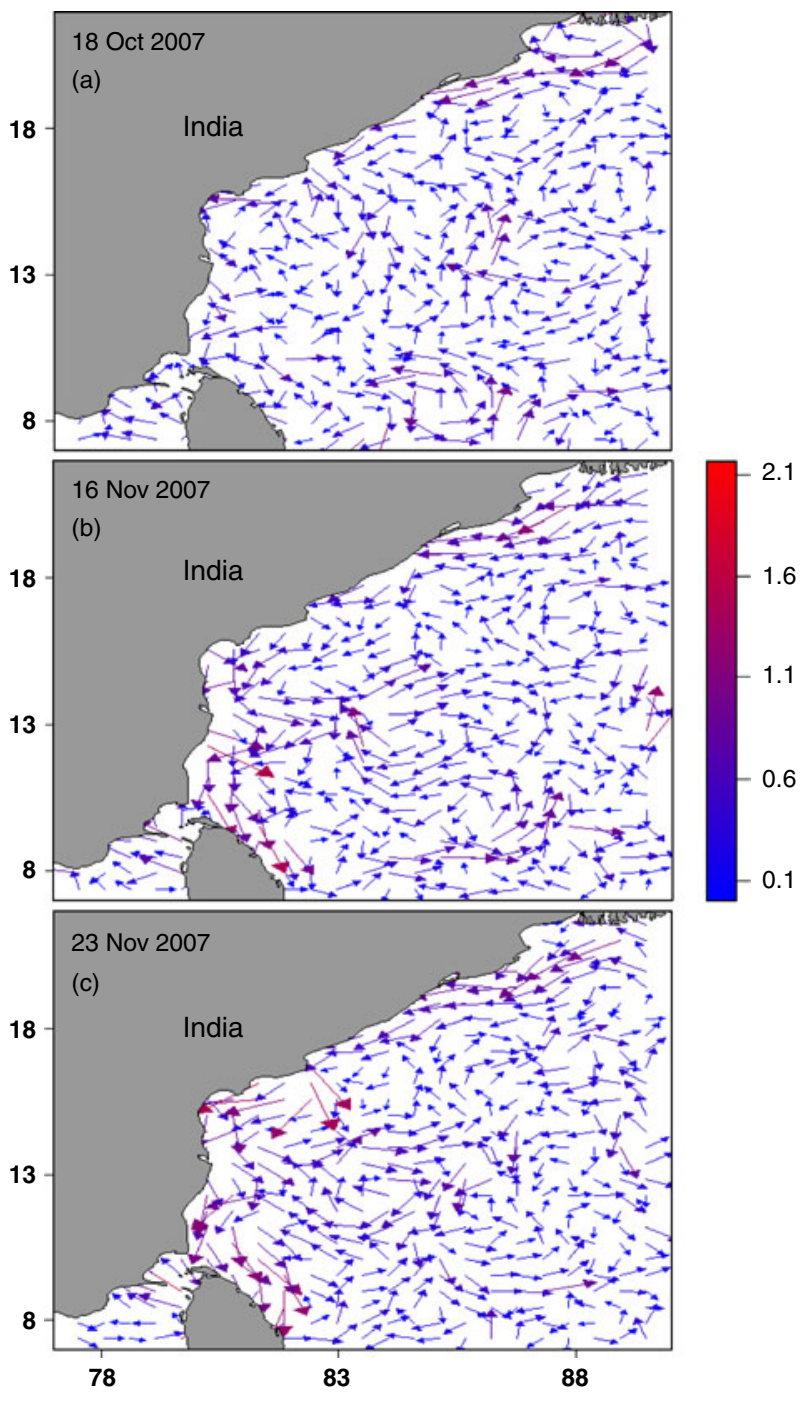

Figure 4. Near surface currents from TOPEX-POSIDEON altimeter during (a) 18 October 2007, (b) 16 November 2007, and (c) 23 December 2007.

\subsection{Influence of cyclone Sidr on phytoplankton blooms}

The cyclone associated with strong winds churn up the upper ocean resulting in enhanced nutrients supply to the surface (Shiah et al 2000). Tropical cyclones occur over the Bay of Bengal throughout the year with minimal frequency in winter (December to February) and maximal frequency in October-November. Changes in coastal circulation associated with cyclones are important along the west coast of Bay of Bengal as they determine horizontal and vertical supply of nutrients. The EICC changes its movement from poleward in summer to equatorward in post-monsoon (Shetye et al 1996). Therefore, irrespective of the place where a cyclone hits the coast, its impact can possibly be observed along the entire Indian coast aided by equatorward/poleward flowing EICC during post- and pre-monsoons, respectively. Vinaychandran (2009) also showed the importance of the EICC in the distribution of $\mathrm{Chl} a$ along the east coast of India.

The winds over the Bay of Bengal were in the NE (northeast) direction before the initiation of cyclone Sidr and atmospheric pressure was relatively low $(1007 \mathrm{mb})$ over the sea compared to that over the land (1012 mb). Relatively high pressure was observed over the NE Bay of Bengal. The SST in the NW Bay of Bengal was $28.5^{\circ} \mathrm{C}$ to $29.5^{\circ} \mathrm{C}$ and Chl $a$ was low $\left(<0.2 \mathrm{mg} \mathrm{m}^{-3}\right)$. On 10 November 2007, a low pressure cell (1004 mb) developed in the southeastern Bay of Bengal, close to AndamanNicobar Islands. It moved in a northwesterly direction initially and intensified over the central Bay of Bengal and moved northerly along $89.5^{\circ} \mathrm{E}$. The pressure at the centre of the storm was $944 \mathrm{mb}$ and the maximal wind was $58 \mathrm{~m} \mathrm{~s}^{-1}$ at the peak intensity of the storm. After the passage of the cyclone Sidr, cooling of $2^{\circ}-3^{\circ} \mathrm{C}$ at the surface was found in the central Bay of Bengal along the cyclone track (figure 5c). Chl $a$ images suggest that their concentrations were low before cyclone $\left(<0.1 \mathrm{mg} \mathrm{m}^{-3}\right)$ but increased to $>0.5 \mathrm{mg} \mathrm{m}^{-3}$ (by $400 \%$ ) to the right of the cyclone track (figure $5 \mathrm{~d}-\mathrm{f}$ ).

The SST change along the cyclone path (over $1400 \mathrm{~km}$ ) was used to examine the impact of cyclone Sidr. The cyclone resulted in a mean SST decrease of about $2.25^{\circ} \mathrm{C}$ along the track (figure $5 \mathrm{c})$. These results are consistent with the earlier studies (Senjyu and Watanabe 1999; Lee and Niller 2003; Babin et al 2004; Smitha et al 2006; Sengupta et al 2007) which showed SST decrease of $2-7^{\circ} \mathrm{C}$. For instance, Smitha et al (2006) reported that SST cooled by $4-5^{\circ} \mathrm{C}$ due to May 2003 (1119) cyclone in the Bay of Bengal. Wind-forced upwelling by the cyclone Sidr resulted in cooling of surface layer (Price 1981). Vertical displacement $(\eta)$ of isopycnals due to Sidr was computed using the formula (Babin et al 2004; Price et al 1994):

$$
\begin{gathered}
\eta=\frac{\tau}{\rho_{0} f u_{h}}, \\
\tau=\rho C_{D} U_{10}^{2},
\end{gathered}
$$

where $\tau$ is the wind stress $\left(\mathrm{N} \mathrm{m}^{-2}\right), \rho_{0}$ is the sea water density of the upper layer $\left(1026 \mathrm{~kg} \mathrm{~m}^{-3}\right)$, $f$ is the coriolis parameter $(=2 \Omega \sin \Phi), u_{h}$ is the transit speed $\left(\mathrm{m} \mathrm{s}^{-1}\right)$ of the storm, $\rho$ is the density of air, $U_{10}$ is the wind speed $\left(\mathrm{m} \mathrm{s}^{-1}\right)$, and $C_{D}$ is the drag coefficient for wind stress. Jarosz et al (2007) showed that $C_{D}$ increases with wind speed and reaches its highest at $32 \mathrm{~m} \mathrm{~s}^{-1}$ but slowly decreases as the speed intensifies under storming conditions. Hence, $C_{D}$ is considered as $1.45 \times 10^{-3}$ for a wind speed of $47 \mathrm{~m} \mathrm{~s}^{-1}$ in case 

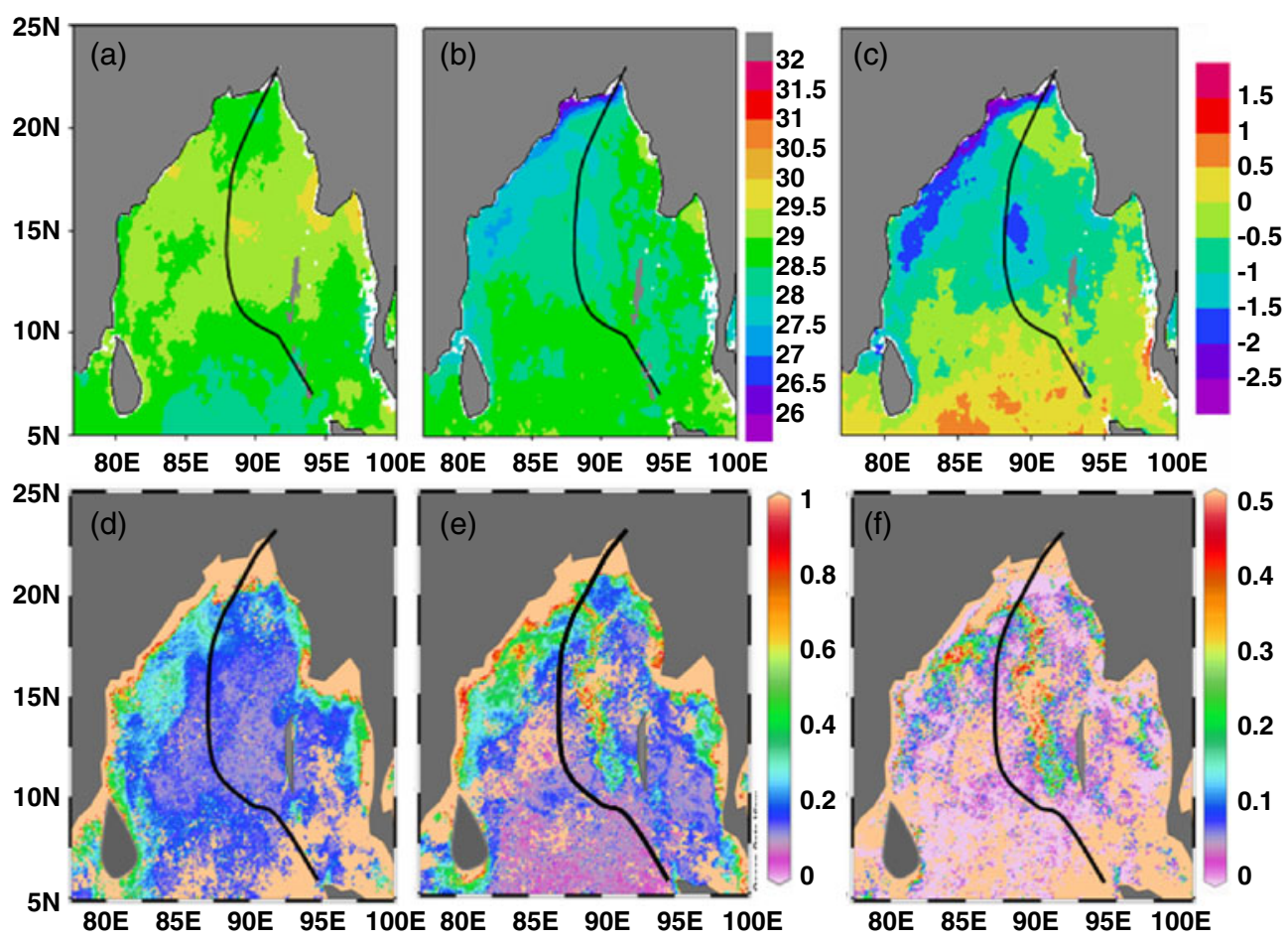

Figure 5. Weekly images of sea surface temperature $\left({ }^{\circ} \mathrm{C}\right)(\mathbf{a})$ before cyclone, (b) after cyclone, and (c) difference between after and before cyclone. Similarly $(\mathbf{d}-\mathbf{f})$ are Chlorophyll $a$. The track of cyclone Sidr is shown in all.

of Sidr (IMD 2008). $u_{h}$ is computed from the 3 hourly storm track positions, which is $5 \mathrm{~m} \mathrm{~s}^{-1}$. $\phi$ is considered as $18^{\circ} \mathrm{N}$. From the computation, using the above considerations, $\tau$ is found to be $3.84 \mathrm{~N} \mathrm{~m}^{-2}$ and $\eta$ to be about $20 \mathrm{~m}$. These are comparable with those reported for the cyclone 'Michael 2000' (3.93 $\mathrm{N} \mathrm{m}^{-2}$ and $24.89 \mathrm{~m}$ ) by Babin et al (2004). To quantify the upwelled nutrients, relationships for SST with nutrients (nitrate, phosphate and silicate) were established using the World Ocean Circulation Experiment (WOCE) data in the Bay of Bengal (I09 transect). Though inter-annual variability in concentration of nutrients in the surface is large (1.1, 0.2 and $0.6 \mu \mathrm{mol} \mathrm{kg} \mathrm{kg}^{-1}$ of nitrate, phosphate and silicate respectively) compared to subsurface waters $\left(0.4,0.1\right.$ and $0.4 \mu \mathrm{mol} \mathrm{\textrm {kg } ^ { - 1 }}$ respectively; our unpublished data); the SST exhibited negative relationships with nutrients (using below mixed layer to $100 \mathrm{~m}$ ) revealing that a decrease in $1{ }^{\circ} \mathrm{C}$ SST resulted in increase of nitrate, phosphate and silicate by $2.85 \pm 0.6,0.2 \pm 0.08$ and $2.02 \pm 0.3 \mu \mathrm{mol} \mathrm{kg}{ }^{-1}$, respectively. Based on this, the expected increase in nutrients in the surface layer amounts to $5.6 \pm 0.8,0.5 \pm 0.1$ and $4 \pm 0.6 \mu \mathrm{mol} \mathrm{kg} \mathrm{kg}^{-1}$, respectively. The quantitative estimation of nutrients may be biased as nutrient levels in the subsurface layers (below mixed layer) are assumed to be constant. Nevertheless, this allows a rough estimation on increased nutrients due to passage of cyclone Sidr. The average $\mathrm{Chl} a$ concentration along the cyclone track before the cyclone was $0.1 \mathrm{mg} \mathrm{m}^{-3}$, that increased to $>0.5 \mathrm{mg} \mathrm{m} \mathrm{m}^{-3}$ (a rise by about 4 times) after the event (figure 5f). Using the assimilation rates of phytoplankton in the Bay of Bengal as 10-80 mgC mgChl- $a^{-1} \mathrm{~d}^{-1}$ (Madhupratap et al 2003) and mean increase in Chl $a$ as $0.7 \mathrm{mg} \mathrm{m}^{-3}$ along the cyclone track, the increase in surface primary production due to cyclone $S i d r$ was estimated to be $7-56 \mathrm{mgC} \mathrm{m}^{-3} \mathrm{~d}^{-1}$. Madhu et al (2002) also found enhanced primary production of 1.8 to $64 \mathrm{mgC} \mathrm{m} \mathrm{m}^{-3} \mathrm{~d}^{-1}$ along the southwest coast of Bay of Bengal following the super cyclone 1999 (25-29 October 1999).

Cool waters (up to $1.5^{\circ}$ to $2.0^{\circ} \mathrm{C}$ ) and high $\mathrm{Chl} a$ $\left(>0.5 \mathrm{mg} \mathrm{m}^{-3}\right)$ was observed along the west coast of Bay of Bengal till north of $13^{\circ} \mathrm{N}$ (figure $5 \mathrm{e}-\mathrm{f}$ ) suggesting that cyclone Sidr in the central Bay of Bengal has significant impact on the biogeochemistry of the west coast of Bay of Bengal. In order to examine this, the wind direction and atmospheric pressure were examined before, and during cyclone Sidr in the western Bay of Bengal. The winds over the Bay of Bengal were in NE (northeast) direction before the cyclone Sidr and atmospheric pressure was relatively high $(1012 \mathrm{hPa})$ over the land and NW Bay of Bengal. The SST in the NW Bay of Bengal was $28.5^{\circ}-29.5^{\circ} \mathrm{C}$ and $\mathrm{Chl} a$ was $<0.2 \mathrm{mg} \mathrm{m}^{-3}$. After the development of cyclone 
Sidr on 10 November 2007, in the southeastern Bay of Bengal and its northerly movement resulting in a change in the wind direction from the NE to NW in the entire northern Bay of Bengal. The change in the wind direction favoured coastal upwelling along the northwestern Bay of Bengal coast that led to cooling of sea surface and an enhancement in nutrients along the west coast. In addition to this, after cyclone Sidr hit west Bangladesh on 15th November night with a storm surge of $4-5 \mathrm{~m}$ height, churned the upper few meters of water column that led to cooling of SST and enhancement of Chl $a$ concentrations at the head of the Bay of Bengal. The enhanced Chl $a$ in the northern Bay coastal waters was due to injection of significant quantities of nutrients through processes such as strong vertical mixing in the coastal and offshore waters, and drainage of terrigenous nutrients after landfall. These nutrient-rich northern Bay (Bangladesh coast) waters spread all along the west coast of Bay of Bengal aided by the strong equatorward flow of EICC during November (Shetye et al 1996). High Chl $a$ was found along the west coast of Bay of Bengal up to north of $13^{\circ} \mathrm{N}$ and then decreased southward (figure 6f). This suggests that although

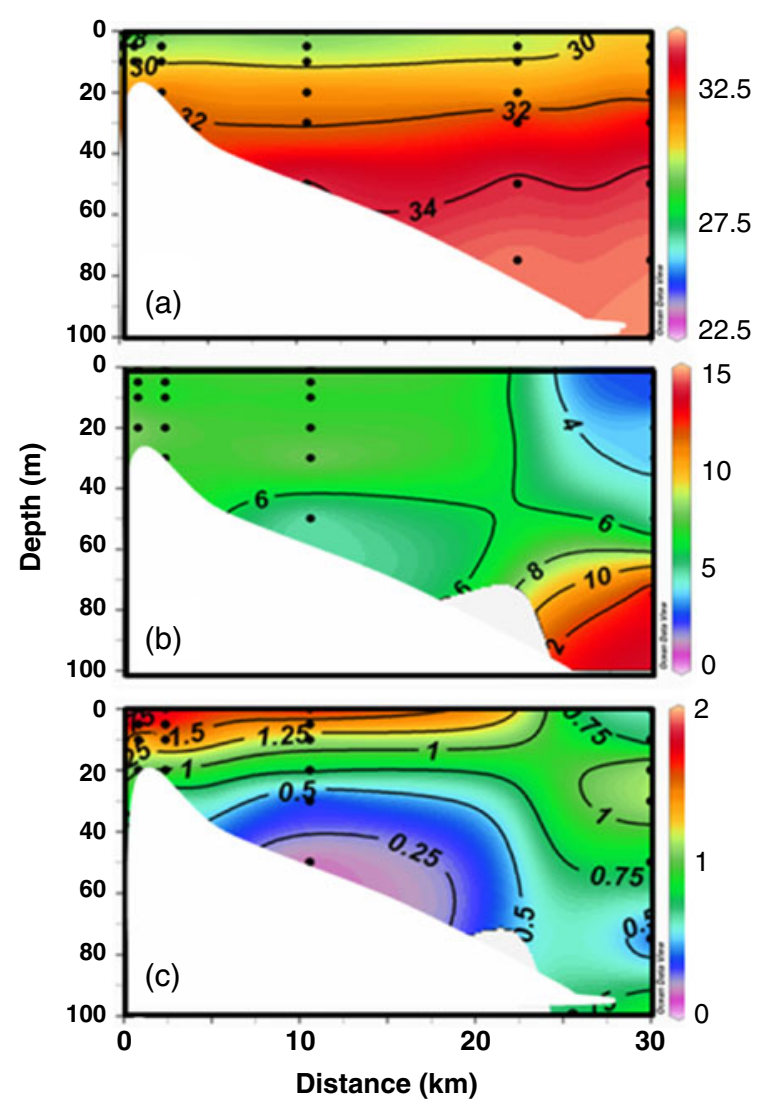

Figure 6. Variation of (a) salinity, (b) nitrate $\left(\mu \mathrm{mol} \mathrm{kg}{ }^{-1}\right)$, and (c) Chlorophyll $a\left(\mathrm{mg} \mathrm{m}^{-3}\right)$ on 19 November 2007. the cyclone hit the northern coast, high Chl $a$ patch $\left(>0.5 \mathrm{mg} \mathrm{m}^{-3}\right.$ ) was observed along considerable part of the western coastal Bay of Bengal due to both coastal upwelling, driven by change in wind direction, and southward spread of nutrients and Chl $a$ rich water.

This is further supported by measured physical and biochemical data at time-series stations off Visakhapatnam. Relatively lower salinity $(<30)$ was observed in the upper $10 \mathrm{~m}$ of water column compared to that of the depth below $(\sim 32$; figure $6 \mathrm{a})$. High nitrate $\left(\sim 5.6 \mu \mathrm{mol} \mathrm{kg}{ }^{-1}\right.$; figure $\left.6 \mathrm{~b}\right)$ and silicate $\left(12-19 \mu \mathrm{mol} \mathrm{\textrm {kg } ^ { - 1 }}\right.$; figure $\left.6 \mathrm{c}\right)$ concentrations were observed in the upper $25 \mathrm{~m}$ of water column during 27 November 2007 than in Novem-

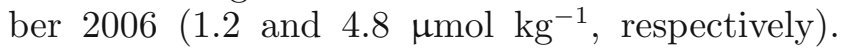
Similarly Chl $a$ concentration was higher in the upper $10 \mathrm{~m}$ (1.25 to $1.75 \mathrm{mg} \mathrm{m}^{-3}$; figure $\left.6 \mathrm{~d}\right)$ than in $2006\left(<0.5 \mathrm{mg} \mathrm{m}^{-3}\right)$ suggesting that advection of low salinity and high nutrient waters from the north supported high plankton biomass during November 2007 off Visakhapatnam. Altimeter data (www.aoml.noaa.gov) indicated that the strength of the EICC was $>1 \mathrm{~m} \mathrm{~s}^{-1}$ during this period (figure 4). Even considering the minimum speed of $1 \mathrm{~m} \mathrm{~s}^{-1}$, EICC can potentially carry nutrientrich waters from Bangladesh coast to the central west coast of the Bay of Bengal (transect shown in figure 1) in about 8 days time (i.e., 23rd November). The observations were taken on 27 November 2007, 12 days after the landfall of Sidr and it is quite possible that northern Bay waters might have reached to the study area well before 28 November 2007. The surface circulation derived for selected dates during October-December 2007 supported the above view (figure 4) and the signatures could be seen in the increased nutrients observed off Visakhapatnam (figure 6). These observations strongly suggest that nutrients supplied by both vertical mixing of water aided by heavy winds and land drainage associated with the cyclone Sidr supported phytoplankton blooms along the west coast of Bay of Bengal in November 2007. From this it may be inferred that the cyclones during OctoberDecember period, which hit either east coast or northern coast (West Bengal and Bangladesh) may cause phytoplankton blooms all along the east Indian coast within few days aided by EICC.

\subsection{Impact of extreme atmospheric events in the northern Bay of Bengal}

To examine the impact of extreme atmospheric events in different regions of the Bay of Bengal, time-series variations in Chl $a$ is studied. Three regions were selected to understand variations in $\mathrm{Chl} a$ in coastal region due to heavy rainfall and 


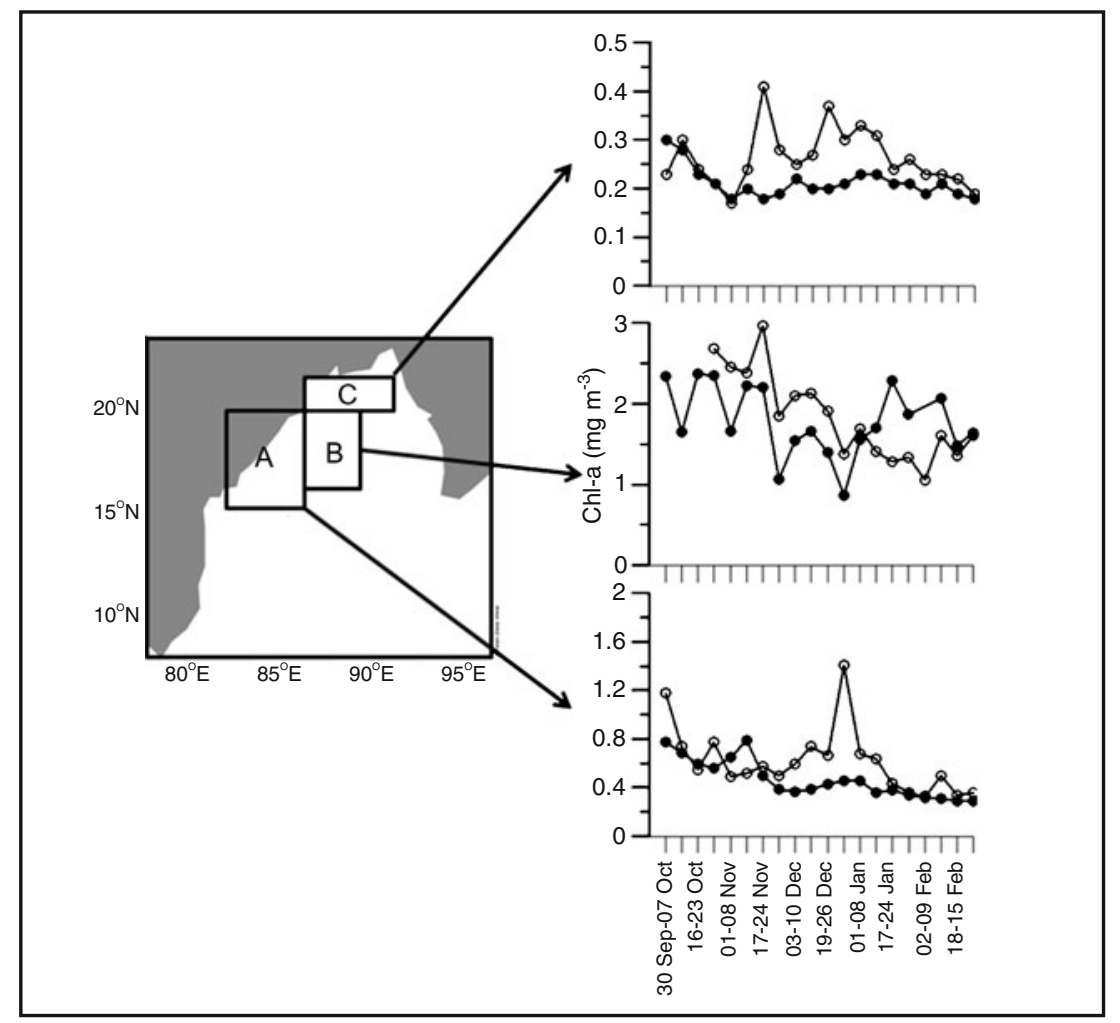

Figure 7. Changes in weekly averaged Chl $a\left(\mathrm{mg} \mathrm{m}^{-3}\right)$ in box A $\left(15-20^{\circ} \mathrm{N} ; 80-87^{\circ} \mathrm{E}\right)$, box $\mathrm{B}\left(16-20^{\circ} \mathrm{N} ; 87-90^{\circ} \mathrm{E}\right)$ and box C $\left(20-22^{\circ} \mathrm{N} ; 87-92^{\circ} \mathrm{E}\right)$ during 30 September to 5 March of 2006-2007 (closed circles) and of 2007-2008 (open circles).

cyclone Sidr (box A; $15-20^{\circ} \mathrm{N}, 80-87^{\circ} \mathrm{E}$ ), influence of cyclone Sidr in the central Bay of Bengal (box B; $16-20^{\circ} \mathrm{N}, 87-90^{\circ} \mathrm{E}$ ) and also in the northern Bay of Bengal (box C; $20-22^{\circ} \mathrm{N} ; 87-91^{\circ} \mathrm{E}$ ) (figure 7 ). The average $\mathrm{Chl} a$ in each of these boxes during September 2006-February 2007 periods of 2007-2008 were presented in figure $7(\mathrm{a}-\mathrm{c})$. The Chl a concentration during 30 September to 07

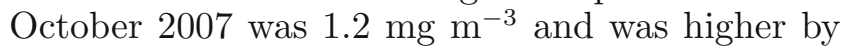
195\% than that in 2006-2007. Again higher concentrations of Chl $a$ was observed between 1724 November 2007 and 2-9 February 2008 and the average increase in Chl $a$ during this period was about $270 \%$ compared to that of the same period during 2006-2007. The increase in Chl a during cyclone Sidr period was much larger in box B (420\%) than in C (310\%). Vinaychandran (2009) analysed annual cycle of Chl $a$, from about 10 years data, in different regions of Bay of Bengal to understand the influence of different rivers. He observed that the influence of Irrawaddy and Ganges-Brahmaputra is larger compared to Mahanadi, Krishna and Godavari rivers. Nevertheless, the amplitude of variations in Chl $a$ in box A (box C in case of Vinaychandran 2009) was $\sim 0.5 \mathrm{mg} \mathrm{m}^{-3}$ on annual scale, and the observed variation in this study during October-December 2007 was much larger $\left(\sim 1.5 \mathrm{mg} \mathrm{m}^{-3}\right)$ than the annual variations suggesting that impact of atmospheric events could be larger than the intra-annual variations. Fishery production off Visakhapatnam was found to have increased by $\sim 40 \%$ during October-December 2007 (5220 tonnes) compared to that of 2006 (3260 tonnes) (Dr Y Basha, Fisheries Survey of India, Visakhapatnam, personal communication) in response to increased phytoplankton biomass. Due to the availability of food, secondary production is expected to increase with a time lag of several days to weeks (Naqvi et al 2002) that attracts fish community. Solanki et al (2005) also found that potential fishing zones were associated with high $\mathrm{Chl} a$ frontal regions in the northern Indian Ocean. Therefore, this study suggests that extreme atmospheric events have significant impact not only on the region of their occurrence but also spread to other regions in a few days to weeks wherein the effect can be noticed up to tertiary levels of the food chain (fishery production).

\section{Summary and conclusions}

The influence of extreme atmospheric events on the occurrence of phytoplankton blooms were studied in the Bay of Bengal. This study revealed 
that extreme rainfall of $234 \mathrm{~mm}$ in a day resulted in enhanced nutrients to the coastal ocean that increased Chl $a$ concentration by $>4$ times within few days to that of normal. These blooms were advected both southward and offshore by EICC. The nutrients enhanced by episodic heavy rainfall event supported phytoplankton for about 2 weeks. Similarly, cyclone Sidr also enhanced Chl $a$ to the right of the cyclone track by $>4$ times in the central Bay of Bengal after the passage of cyclone. The cyclone Sidr hit west Bangadesh coast with a storm surge of $4-5 \mathrm{~m}$ height and thoroughly churned the water of the head Bay of Bengal. These nutrient-rich waters were advected to the south along the west coast of Bay of Bengal until $13^{\circ} \mathrm{N}$ and diluted further by EICC. Enhanced nutrients and Chl $a$ concentrations in the coastal waters were observed even after cyclone Sidr. These two events caused phytoplankton blooms along the western Bay of Bengal, which enhanced the fishery production by $40 \%$ during October-December in 2007 compared to that of 2006 . Thus, the episodic events, therefore, brought significant amount of nutrients to the photic zone and supported phytoplankton for about 2-3 weeks. The Bay of Bengal is generally considered to be a low productive region compared to the Arabian Sea based on extra/interpolation of seasonal measured data or monthly mean productivity estimates from $\mathrm{Chl} a$ images. These estimates do not include influence of such episodic atmospheric events studied here. This study suggests that episodic extreme atmospheric events may affect the overall annual carbon budget and cannot be neglected. The intensity and periodicity of these processes and their quantitative significance need to be evaluated using long term time-series remote sensing data together with in situ observations.

\section{Acknowledgements}

The authors would like to thank Director, NIO, Goa and Scientist-in-charge of Regional Centre, Visakhapatnam, for their keen interest and encouragement. The present work was carried out as a part of the project funded by the Department of Science and Technology, related to Surface Ocean Lower Atmosphere Study (SOLAS). The senior author (KM) thanks Department of Science and Technology (DST) for financial support and also CSIR (Council of Scientific and Industrial Research, New Delhi) for providing the Senior Research fellowship. The authors would like to acknowledge SeaWiFS, MODIS and AOML for making available satellite derived Chlorophyll $a$, SST and altimeter data. The authors are thankful to two anonymous reviewers for their valuable suggestions which helped to improve the original version of the manuscript. This is NIO contribution number 4924.

\section{References}

Babin S M, Carton J A, Dickey T D and Wiggert J D 2004 Satellite evidence of hurricane-induced phytoplankton blooms in an ocean desert; J. Geophys. Res. 109 C03043, doi: 10.1029/2003JC001938.

Gomes H R, Goes J I and Saino T 2000 Influence of physical processes and freshwater discharge on the seasonality of phytoplankton regime in the Bay of Bengal; Cont. Shelf Res. 20 313-330.

Grasshoff K, Ehrhardt M and Kremling K (eds) 1983 Methods of Seawater Analysis; Weinheim: Verlag Chemie, pp. $89-224$.

IMD 2008 Report on Cyclone Disturbances over North Indian Ocean during 200\%, RSMC-Tropical cyclones, India Meteorological Department, New Delhi.

Jarosz E, Mitchell D A, Wang D W and Teague W J 2007 Bottom-up of air-sea momentum exchange under a major tropical cyclone; Science 315 1707-1709.

Lafond E C 1966 Bay of Bengal; In: The Encyclopedia of Oceanography (ed.) Fairbridge R W, Van Nostrand Reinhold Co., New York, 110-118.

Lee D and Niller P 2003 Ocean responces to typhoon Rusa in the south sea of Korea in the East China Sea; J. Korean Soc. Oceanogr. 38 60-67.

Madhu N V, Maheswaran P A, Jyothibabu R, Sunil V, Revichandran C, Balasubramanian T, Gopalakrishnan T C and Nair K C 2002 Enhanced biological production off Chennai triggered by October 1999 super cyclone (Orissa); Curr. Sci. 82 1472-1479.

Madhupratap M, Gauns M, Ramaiah N, Prasanna Kumar S, Muraleedharan P M, de Souza S N, Sardessai S and Usha M 2003 Biogeochemistry of the Bay of Bengal: Physical, chemical and primary productivity characteristics of the central and western Bay of Bengal during summer monsoon 2001; Deep-Sea Res. II 50 881-896.

Nayak S R, Sarangi R K and Rajawat A S 2001 Application of IRS-P4 OCM data to study the impact of cyclone on coastal environment of Orissa; Curr. Sci. 80 1208-1213.

Naqvi S W A, Sarma V V S S and Jayakumar D A 2002 Carbon cycling in the northern Arabian Sea during the northeast monsoon: Significance of salps; Mar. Ecol. Prog. Ser. 226 35-44.

Patra P K, Kumar M D, Mahowald N and Sarma V V S S 2007 Atmospheric deposition and surface stratification as controls of contrasting chlorophyll abundance in the North Indian Ocean; J. Geophys. Res. 112 C05029, doi: 10.1029/2006JC003885.

Prasanna Kumar S, Muraleedharan P M, Prasad T G, Gauns M, Ramaiah N, de Souza S N and Madhupratap M 2002 Why is the Bay of Bengal less productive during summer monsoon compared to the Arabian Sea? Geophys. Res. Lett. 29 2235, doi: 10.1029/2002GL016013.

Price J F 1981 Upper ocean response to hurricane; J. Phys. Oceanogr. 11 153-175.

Price J F, Sanford T B and Forristall G Z 1994 Forced stage response to a moving hurricane; J. Phys. Oceanogr. 24 233-260.

Qasim S Z 1977 Biological productivity of the Indian Ocean; Indian J. Mar. Sci. 6 122-137.

Radhakrishna K, Bhattathiri P M A and Devassy V P 1978 Primary productivity of Bay of Bengal during AugustSeptember 1976; Indian J. Mar. Sci. 7 94-98. 
Rao K H, Smitha A and Ali M M 2006 A study on cyclone induced productivity in southwestern Bay of Bengal during November-December 2000 by MODIS (SST and Chlorophyll- $a$ ) and altimetry sea surface height observation; Indian J. Mar. Sci. 35 153-160.

Sarma V V, Sadhuram Y, Sravanthi N and Tripathy S C 2006 Role of physical processes in the distribution of Chlorophyll- $a$ in the northwestern bay of Bengal during pre- and post-monsoon; Curr. Sci. 91 11331134 .

Sengupta D, Raj G B and Anitha D S 2007 Cyclone induced mixing does not cool SST in the post monsoon north Bay of Bengal; Atmos. Sci. Letts. 9 1-6.

Senjyu T and Watanabe T 1999 A sudden temperature decrease along the Sanin coast induced by a typhoon; Umi to Sora 75 1-8 (in Japanese with English abstract).

Shetye S R, Gouveia A D, Shankar D, Shenoi S S C, Vinayachandran P N, Sundar D, Michael G S, Nampoothiri G 1996 Hydrography and circulation in the western Bay of Bengal during the northeast monsoon; J. Geophys. Res. 101 14,011-14,025.

Shiah F K, Liu K K, Kao S J and Gong G C 2000 The coupling of bacterial production and hydrography in the southern East China Sea; Cont. Shelf Res. 20 459-477.

Smitha A, Rao K H, Sengupta D 2006 Effect of May 2003 tropical cyclone on physical and biological processes in the Bay of Bengal; Int. J. Remote Sens. 27 53015314.

Solanki H U, Mankodi P C, Nayak S R and Somvanshi V S 2005 Evaluation of remote-sensing-based potential fishing zones (PFZs) forecast methodology; Cont. Shelf Res. 25 $2163-2173$.

Suzuki R and Ishimaru T 1990 An improved method for the determination of phytoplankton chlorophyll using N,Ndimethylformamide; J. Oceanogr. 46 190-194.

UNESCO 1979 Discharges of selected rivers of the World, Paris.

Varkey M J, Murty V S N and Suryanarayana A 1996 Physical oceanography of the Bay of Bengal and Andamann Sea; In: Oceanography and marine biology. An Annual Review, (eds) Ansel A D, Gibson R D and Barnes N, UCL Press, 34 1-70.

Venkateswarlu S and Sudhavalli S 2010 Exceptionally heavy rainfall at Visakhapatnam on 4.10.2010: A Doppler Weather Radar explanation; Advances in weather and climate services (TROPMET-2010), held at Kolkata during 19-21 May 2010.

Vinayachandran P N and Mathew S 2003 Phytoplankton bloom in the Bay of Bengal during the northeast monsoon and its intensification by cyclones; Geophys. Res. Lett. 30 1572, doi: 10.1029/2002GL016717.

Vinayachandran P N, McCreary Jr J P, Hood R R and Kohler K E 2005 A numerical investigation of the phytoplankton bloom in the Bay of Bengal during northeast monsoon; J. Geophys. Res. 110 C12001, doi: 10.1029/2005JC0029661.

Vinaychandran P N 2009 Impact of physical processes on chlorophyll distribution in the Bay of Bengal; In: Indian Ocean Biogeochemical Processes and Ecological Variability; Geophysical Monograph Series 185, doi: 10.1029/2008GM000705. 